Article reference number : 15-056

Chevron's Gift of CSR: Moral Economies of Connection and Disconnection in a transnational Bangladeshi village

Katy Gardner (Professor of Anthropology, LSE)

Email: K.J.Gardner@LSE.ac.uk

Biography : Katy Gardner's doctoral research examined the cultural and social changes associated with international migration and globalisation in Bangladesh (Global Migrants, Local Lives: Travel and Transformation in Rural Bangladesh, 1995). She has researched age, the life course and childhood amongst British Bangladeshis in London (Age, Narrative and Migration: Bengali Elders in London, 2002) and is also interested in the relationship between anthropology and development (she is co-author (with David Lewis) of Anthropology and Development: Challenges for the Twenty-First Century, 2015). She has recently become interested in natural resources and industrialisation in Bangladesh, in particular the effects of land loss, corporatisation and 'corporate social responsibility' on poverty and inequality and is the author of Discordant Development: Global Capitalism and the Struggle for Connection in Bangladesh (Pluto Press, 2012). 


\title{
Chevron's Gift of CSR: Moral Economies of Connection and Disconnection in a transnational Bangladeshi village
}

\begin{abstract}
Based on ethnographic material gathered from villages surrounding the Bibiyana gas field operated by Chevron in NE Bangladesh, this paper explores the apparent paradox between the corporation's programmes of development and the response of residents who insist that the company 'should do more.' The paper draws upon theories of the development gift which focus upon the ethics and moralities of corporate giving and the ways in which development gifts extend capitalist power, re-embed morality in the market and bind recipients into hierarchical positions of unequal exchange. In contrast, we know significantly less about the moralities and motivations of the populations to whom the gifts are offered. Aiming to fill the lacunae, the paper shows how at Bibiyana the 'Community Engagement' programmes take place in a specific moral terrain which predates the arrival of Chevron and has profoundly affected how their development goods are perceived, utilised and contested. Whilst Chevron's 'Community Engagement' programme is underlain by ethics of detachment (Cross, 2011) and aims to create disconnection via discourses of empowerment and sustainability, this is at odds with the local moral economy of connection, which is underlain by the ethics of Islamic charity and patronage, in which hierarchical differences are explicit.
\end{abstract}

Key words : Development gift, CSR, moral economy, Bangladesh 
March, 2008. I am sitting in the yard of Halema Bibi as she shows me a slab latrine to be fitted at the back of her house, one of the poorest in Talukpur, a village next to the Bibiyana Gas Field in Nabiganj, North East Bangladesh ${ }^{1}$. This, like the concrete pillars of her brother's place opposite is stamped with the logo Chevron. Next to the slab latrine is a smoke free chula (stove), also marked with the company's logo. It's too small for lakri (firewood) Halima tells me; she doesn't use it. I ask what she thinks of the American corporation. In an effort to create local good will the company has embarked upon a programme of 'Community Engagement' including gifts of development such as building materials, slab latrines and chulas to the poorest households. Halema's face darkens. Chevron is looting resources, she says angrily; they give nothing. It is a remark I have heard many times from different people; later, when I recount it to the NGO workers tasked by Chevron to distribute their development largess, they too react with irritation. The problem is not the gifts, they say, but those that receive them, for 'the people are too demanding.'

In what follows I explore the apparent paradox between Chevron 's programmes of 'Community Engagement', which alongside building materials and stoves included micro credit and training aimed at 'empowerment', and the response of a population who deny that they have benefitted or insist that the company 'should do more.' In so doing, I draw upon an emerging literature in the anthropology of development which uses theories of the gift to explicate the social and political relations of development (cf. Stirrat and Henkel, 1997; Korf et al, 2010; Yeh, 2013; Cross, 2014). In particular, my discussion is located in debates surrounding the Corporate Social Responsibility (CSR) programmes of extractive industries, offered as an appeasing gift to populations in the areas where mining takes place (Rajak, 2011; Welker, 2012; 2014; Shever, 2012; Frynas, 2005; Kapelus, 2002; Kirsch, 2014). As Cross observes, this work focusses largely upon the ethics and moralities of corporate giving, describing how the gifts extend capitalist power, re-embedding morality in the market and binding recipients into hierarchical positions of unequal exchange. What we know less about are the moralities and motivations of the populations to whom the gifts (or programmes of development) are offered (Cross, 2014: 214).

In contrast, in this paper I show how in Bibiyana 'Community Engagement' programmes take place in a specific moral terrain which predates the arrival of Chevron and has profoundly affected how their development goods are perceived, utilised and contested. Indeed, whilst Chevron's 'Community Engagement' programme is underlain by ethics of detachment (Cross, 2011) and aims to create disconnection via discourses of empowerment and sustainability, this is at odds with the local moral economy of connection, which is underlain by the ethics of Islamic charity and patronage, in which hierarchical differences are explicit.

\footnotetext{
${ }^{1}$ Like the names of informants, village names have been anonymised.
} 
Before proceeding I should mention that the gas field was developed next to the village where I have doing fieldwork since 1987 (Gardner, 1995; 2008; 2012), an area of sustained long term transnational migration to the UK and elsewhere. This paper arises partly from my long term research on transnational migration but more centrally from a project funded by the ESRC-DFID on the effects of the gas field on transnational networks and livelihoods in which I worked alongside three researchers from Jahangirngar University: Zahir Ahmed, Fatema Bashir and Masud Rana. Our research involved fieldwork in two villages which focussed on household livelihoods and coping strategies, interviews with political leaders in Bangladesh and the UK, interviews and group discussions with transnational villages in the U.K and with Chevron officials and NGO workers in Bibiyana and Dhaka, as well as participant observation, and took place over 2008-11. It should be noted that the situation recounted here is part of a complex and continually unfolding story; what follows is based on a particular period of time and doesn't cover the expansion of the gas field, which took place after 2011.

\section{The Development Gift and CSR}

In their seminal article 'The Development Gift' Stirrat and Henkel argue that despite international development orthodoxies of 'partnership' which imply equality and sameness, development gifts which use NGOs as intermediaries mark difference and hierarchy between givers and receivers; whilst purporting to be non-reciprocated and 'without strings' such gifts are heavy with power and serve to exacerbate dependency and patronage (Stirrat and Henkel, 1997). This argument has been developed by anthropologists focussing on the gifts of mining corporations. Dinah Rajak, for example, analyses the programmes carried out by the Anglo-American mining company in South Africa. Rather than business being amoral, Rajak argues, CSR brings morality into business practice, allowing mining companies to extend moral authority over the places where extraction takes place via discourses that stress partnership, responsibility and so on. Not only do global codes of ethics act as a form of governmentality they also naturalise neoliberal tenets such as entrepreneurship and the role of the market whilst eliding questions of power and ecology. Yet whilst CSR discourses of 'partnership', 'empowerment' and 'participation' allow the company to avoid charges of patronage, on the ground the politics of the gift remain, sometimes forging alliances and reducing conflict but always with the power relations of giver and receiver intact (Rajak, 2011).

In Bibiyana, similar contradictions mark Chevron's programmes, which both attempt to avoid patronage by creating 'sustainable' programmes yet also extend and naturalise Chevron's control over the area. Key to the programme are 'Alternative Livelihood' projects, which are based on the grass-roots approaches of micro-credit, small scale entrepreneurship and 'empowerment' pioneered by Bangladeshi NGOs such as the Bangladesh Rural Advancement Committee (BRAC) and the Grameen Bank (cf Cons and Papricki, 2010; Karim, 2011; Lewis, 2011 and 2004; White, 1999) in which ideologies of 
self-help, sustainability and neo-liberal subjectivities feature large (cf Ong, 2006; Li, 2007; Rose, 2005). Yet whilst one requirement of such programmes is that they gain ethical virtue for the corporation and submerge the hierarchical differences of the exchange, another is that the gift be reciprocated in the form of public displays of gratitude, in which development goods are ceremonially handed over to the grateful poor.

Other research reminds us that security concerns often overshadow the desire for ethical virtue (Zalik, 2004; Welker, 2009; 2012; 2014). Here, despite their packaging in the language of partnership and empowerment, and the 'smiling face' with which they are offered (Shever, 2010; 2012) the gifts of development offered by mining corporations are a territorial strategy and a technique to counter opposition. As this work demonstrates, nowadays PR savvy extractive industries 'want to cuddle' (Burton, 2002) offering a range of donations which attempt to rebrand the corporation as compassionate, caring, in partnership with 'local communities' (Zilak, 2004; Rajak, $2009 ; 2011$ ) or refracting the discourses of environmentalism with which they are critiqued to suggest that they are protecting the environment and contributing to local culture (Welker, 2009; Rogers, 2012; Kirsch, 2010). Meanwhile, even as these manoeuvres result in increased conflict, violence and struggle the programmes ensure that the reputation of the corporation is left intact (see in particular Welker, 2009; Zilak, 2004).

Whilst this valuable work demonstrates how gifts of CSR reproduce capitalist power, controlling and disciplining whilst simultaneously creating binding social relationships between givers and receivers, its focus is largely upon the operations and ethical impulses of the mining corporations rather than the cultural and moral contexts in which the programmes take place. As Jamie Cross points out, in these accounts the exchange can appear to be 'remarkably one sided and remarkably stable. ...the only happenings, meanings and consequences worth recording appear to be those that can be entered into a corporate balance sheet or appear as indices of profit.' (2014: 126). In contrast, Cross argues that corporate gifting can be also be read as a means by which both givers and receivers perform and create identities and personhood. In his ethnography of the gifts of gold coins by the Worldwide Diamonds factory to their employees in South India, for example, he shows how within the perspectives of the employees the gift invokes kingship, caste and religion in ways that reinforce and recreate inter caste relations, implying that Worldwide Diamonds was finally behaving as a benevolent patron who acknowledged the inalienable flow of their labour, and with whom transactions were embedded in social relationships and personhood (ibid: 139).

As this shows, by shifting the research gaze from the motivations and impulses of those who offer to those who receive, corporate gifts become meaningful in another way. In contrast to the gifts of Worldwide Diamonds, however, in Bibiyana the corporate gift of programmes of 'empowerment' and 'self help' was not met with satisfaction but the opposite: disgruntlement and a sense that the company was neglecting its 
responsibilities. And whilst in Cross's South Indian ethnography the rituals of giving marked differences between donor and recipients in ways that were culturally and historically appropriate, in Bibiyana the gifts supress hierarchy and patronage, denying recipients the possibilities of long term connection with the corporation. Here, corporate gift exchange emerges as an arena in which the different moralities and expectations of the givers and receivers clash. Indeed, rather than the CSR gifts being received in the corporation's imagined world of simple material needs and romanticised village life (cf Inden, 1990; Cons and Paprocki, 2010) featuring compliant villagers eager for 'empowerment', to be bestowed not by a detached though concerned corporation, the reality was more tricky. Not only was there considerable protest at the loss of land and livelihoods associated with the gas field but the CSR gifts were offered to a population who already had strong expectations regarding gift exchanges between poor people and wealthy foreigners (bideshi : foreigners; also used to refer to migrants who have settled abroad). These expectations were underlain by a moral economy based upon the central ethic of social connection and rights over land-use, which ran contrary to the ethics of detachment underlying the corporate gift. Unlike Cross's South Indian ethnography, in Bibiyana the exchange thus involved diametrically different ways of being and knowing.

\section{Moral Economies of Connection and Disconnection}

How are we to make sense of the complex responses of local people to Chevron's corporate gifts? As we shall see, these gifts changed over time, as did Chevron's position as giver. Though originally appearing to fit the part of a powerful patron, later those charged with 'Community Engagement' attempted to construct the corporation as a concerned and benevolent presence overseeing sustainable development and empowerment for humanitarian rather than political reasons ${ }^{2}$. In order to frame the different motivations, expectations and responses of givers and receivers in what follows I use the concept of 'moral economy' as a heuristic device. This is classically described by E.P.Thompson as ' a traditional view of the social norms and obligations, of the proper economic functions of several parties within the community, which taken together can be said to constitute the moral economy of the poor.' (Thompson, 1971: 79). As Thompson suggests, belief in the proper working of the moral economy is often passionate; rebellion will result if the obligations are not met, an insight reworked by James Scott in his seminal work on the 'moral economy of the peasant' South East Asia (Scott, 1976; see also Edelman, 2005).

As I will argue, within the exchange of corporate gifts in Bibiyana two moral economies can be discerned. The first is what I term a 'moral economy of connection' amongst the people supposed to be the grateful recipients of Chevron's gifts. Shaped by the region's

\footnotetext{
2 As Fassin argues, humanitarianism, aimed at distant strangers with whom one has no social relationship, is a powerful source of anti-politics (Fassin, 2012)
} 
long history of migration to the UK, this involves the values and expectations of kinship and charity plus a strong sense of rights over local resources, gained by connection to the desh (homeland) via residence and kinship. In this moral economy wealthy patrons, many of whom live in the UK, have a duty of charitable giving to their 'own poor' in the desh. Within this logic, Chevron - a powerful and hugely wealthy corporation - was placed under similar obligations. Meanwhile the corporation's use of the gas - a natural resource shared by local people - meant that it should provide payment in kind, in the shape of building hospitals and schools providing jobs for local people. Yet as I show in the second half of the paper, the CSR programmes were dictated by the logic of an entirely different moral economy, one which denies connection, dictated instead by what Cross has called 'the corporate ethic of detachment' (Cross, 2011), or what in the context of Bibiyana I call a 'moral economy of disconnection' (Gardner, 2012). Here, the corporation takes a position of concerned detachment, seeking to produce humanitarian social good via business but denying long term social relationships and submerging the hierarchy of the gift via the anti-politics of discourses of 'sustainability' and 'self help'. Whilst analytically distinct, the differences between these moral economies is not always clear to those who give or indeed those who receive. Instead, at times they remain submerged or flattened, their sharp edges only appearing at certain moments or materialised by particular gifts, when the expectations of the parties (for particular gifts or for reciprocity in the form of gratitude) are disappointed.

\section{A Moral Economy of Connection : Transnational Migration and Patronage in Bibiyana}

Like other parts of Sylhet, Bibiyana has had a long and intimate relationship with the global economy, via the lascars who worked on British ships from the beginning of the Twentieth Century, the men who left for Britain in their thousands from the 1960s onwards, and their families who settled in the UK with them since the 1980s (Adams, 1987; Gardner 1995; 2008)3. The migrants originally spent their earnings on buying land, building houses, and transforming their status. By the 1980s, they owned almost all the local land whilst those families who hadn't migrated had slipped down the scale to become landless or land poor. Local economic and political hierarchies were therefore dominated by relative access to the U.K. and other foreign destinations. These inequalities took on a distinctive local pattern, adhering to kinship networks. In the village closest to the gas field, which was originally settled by in-migrant labourers, noone had the economic or social capital necessary for migration and at the time of our research the village was over $80 \%$ landless, far higher than the national average of $56 \%$ (Toufique and Turton, 2002); a high preponderance of people lived in mud and thatch dwellings and no-one had electricity. Our research found that many landless people in our study villages did not have basic food security.

\footnotetext{
${ }^{3}$ For a broader history of migration and movement in the region see Amrith, 2013; Samaddar, 1999
} 
Despite the long term settlement of Londoni families in the U.K. transnational migration has continued to dominate the local economy, for transnational 'help' is central to the livelihoods of many people, either in the form of regular remittances for those with close Londoni relatives, or an irregular lump sum in times of need or crisis. When we asked the poor how they coped during crises, we learnt not only of disastrous floods, illnesses and accidents, but also how they were saved by gifts or loans from Londonis. These gifts are also extended to unrelated poor. In the U.K, for example, we met a man whose family fund the education of several children from unrelated and landless families in his village. Such transnational 'help' (shahajo) is linked to the Islamic practice of Jakat, in which a proportion of a household's wealth is donated to charity each year. Amongst people from Bibiyana living in the UK the donation of Zakat is done back in the desh via mosque committees and organised around the notion of 'our own poor'. A man from Talukpur who currently runs several restaurants in the north of England told me that he was spiritually obliged to give a proportion of his wealth to the poor (garib) of his village; the idea of giving charity in the UK was preposterous, he added, for people there were not poor. In a similar spirit, when cattle are sacrificed in the Islamic festival of Qurbani Eid, a portion of the meat is distributed to landless people who go from house to house collecting their share. Again, Londonis send money to their relatives in the desh, in order that the sacrifices are carried out in their ancestral villages.

More generally, the giving of charity (dewa) is believed to create spiritual merit; beggars who wander from village to village are given a bowl of chaal (unhusked rice) or a meal. The Islamic injunction to give charity underpins a moral order in which one should endeavour to support and look after 'one's own poor', starting with close relatives and extending outwards to those with more tenuous kinship connections, who might eventually be related only by geographical proximity: neighbours or servants (Gardner and Ahmed, 2009). The recipients of charity are expected to reciprocate with gratitude, political support and demonstrations of subservience. Centrally, the donation is seen as part of an on-going social relationship.

Rooted in Islamic morality but fuelled by migration the transnational economy of connection has become an important survival strategy for the non migrant poor of the locality, who are quick to remind their patrons of their obligations (Gardner, 2012). In my visits to Bibiyana, for example, I, like the transnational villagers in the U.K, am besieged with requests for help from poorer members of the lineage that over the years has become my adoptive family. Whilst requests from beggars or unknown people can be ignored, those from poor relations cannot; indeed, I am given strict instructions by friends of how much I should give to which impoverished cousin or 'auntie'. Londonis face similar demands. In my last visit in 2014, for example, a new house was being built for a family of impoverished cousins living on the margins of the village, paid for by distant cousins living in northern England ${ }^{4}$. Meanwhile, unrelated poor people who

\footnotetext{
${ }^{4}$ I too once paid for a house to be built for a very poor relative (Gardner, 2012).
} 
have a weaker social connection make lesser demands. Take Hushnara Bibi, who came to the house during my visit. In the late 1980s Hushnara had been employed by the family as a bua beti (servant) and had an enduring friendly relationship with the women of the house. Now she was suffering from respiratory problems and needed money for medicine. She sat on the veranda with the women of the house for a while, exchanging news, and then was given some money. It is important to note that this moral economy of connection in which the rich are socially obliged to offer assistance to their 'own poor', in return for on-going political support and subservience (Gardner, 1995) exists in a context where there are only the most rudimentary and piecemeal state welfare programmes, and where the poor largely rely upon NGOs for services (Lewis, 2011; Cons and Papricki, 2010; Karim, 2011).

Whilst the poor seek security via patrons to whom they are connected, a major drawback is that the system depends upon the vagaries of individual patrons. This makes them particularly vulnerable in the context of rapid change and out-migration. Indeed, across Bangladesh industrialisation and urban migration are contributing to a weakening of traditional patron-clientage (cf Kabeer, 2002; Islam, 2002). Londoni families from Bibiyana are increasingly orientated towards Britain, and are returning less. Many younger people do not feel the same amount of obligation as their parents towards distant kin they have only met a few times, and the weight of duty can be heavy. A villager who lives in Newcastle complained that the gifts and 'help' he had to distribute cost him over $£ 10000$ each time he returned home. He wasn't going again, he said. It was too expensive and he had to focus on his new restaurant. The transnational economy of expectation is thus riven with disappointment and insecurity.

The wider context is an agrarian economy that is rapidly changing. During my doctoral fieldwork in the 1980s all the households of my study village were sustained, in part or wholly, by agriculture. Whilst not all owned land, their members either sharecropped fields owned by neighbours or were employed as labourers. Payment was often in kind: sharecroppers took two thirds of the harvest and labourers, who had long term connections of patronage with richer household and were called by fictive kinship terms (mama : sister's brother), were given rice as well as taka in payment, and usually offered longer term charitable support. Whilst fields were privately owned there remained a strong ethos that those within the desh should have rights of use over that land so long as it did not interfere with cultivation. For example, cattle might roam freely over large tracts of land during the dry season and ducks could swim in local ponds. Meanwhile after the harvest anyone might gather loose grains or straw left behind or in the wet season take shrimps or small fish from the waterlogged fields. Within the moral economy of connection these activities - so central to the livelihoods of the poorest people - were a naturalised 'right', arising from long term kinship connections and residence in the area. 
Whilst agriculture remained central to local livelihoods, our research in 2008-11 detailed a noticeable shift to other strategies, including rickshaw or van driving, small businesses and itinerant labouring amongst the poorest inhabitants. This was partly though not wholly due to the loss of land caused by the gas field. Many households complained of the high costs of agriculture due to the inputs of fertiliser, irrigation and labour. Absentee landlords who were based in Britain had little interest in farming and tended not to invest in their land, favouring the rangmati system in which the sharecropper has to pay for initial inputs, making it too expensive for poorer households. Increasingly land was being used for business ventures such as building 'colonies' for in-migrants, fish ponds or poultry farms. Accelerated by transnational migration, the privatisation of resources and movement of people from land-based livelihoods to uncertain futures has been widely reported across South Asia (cf : Corbridge, S. and Shah, A. 2013; Ito, 2002; Walker, 2008: Akram Lodhi, 2009; Feldman and Geisler, 2012; Adnan, 2013; Adduci, 2009). As these processes gather pace, the poorest people, who have no material assets and are increasingly squeezed out of the precarious agrarian economy, are ever more dependent upon the charity of their patrons. Significantly, the gas field has altered the local ecology, meaning that some of the usages of land - grazing cattle, gathering grains (for food) and straw (for fuel) have been severely affected. Little wonder that within the moral economy of connection Chevron were expected to 'pay back' for their use of local resources.

\section{Anticipating Connection : Gas, Development and Disappointment}

If in the moral economy of connection help and charity are expected from transnational patrons, the arrival of Chevron in the area led to both to the expectation that they would provide compensation in kind for their use of local natural resources, as well hopes of good things that would happen in the future. Since they were extracting 'their' gas, local people argued that the corporation should repay them by providing formal employment, schools and hospitals, and, at the top of the list, connection to the actual gas, which none of the villages had. Within the moral economy of connection Chevron were understood by local people as 'owing' them the benefits of modernisation in return for their exploitation of the gas. Indeed, from the outset, the Bibiyana Gas field had evoked both passionate protest and hope ${ }^{5}$. The discovery of natural gas in the area took place in the mid 1990s by the company Occidental. By 2000 Unocal had taken over and a smaller installation at Dikolbakh was constructed; eventually this was to be joined a few miles away by a much large development at Bibiyana. The land - sixty three acres for the site, but more for roads - was forcibly acquired by the Bangladeshi government and rented to Unocal.

\footnotetext{
${ }^{5}$ For further discussion of the ambivalence surrounding sites of industrial development in South Asia see Cross, 2014b
} 
In 2005 Unocal merged with Chevron. By 2007 the Bibiyana Gas Field went into production, joining other gas fields in Sylhet operated by Chevron: Jalalabad and Moulavi Bazaar6. Operating in Bangladesh since the early 2000s, the company is now the country's largest foreign investor and producer of gas, though not without controversy. For example when explorations for gas in the forests of Lawachara in Sylhet led to a fire in 2008, there was widespread condemnation of the company. During the course of our research there were also constant rumours in the national press and blog sites concerning the over exploitation of gas, the extent of the reserves, and accusations (unproven) of corrupt deals with the government (Gardner, 2012). The gas reserves at Bibiyana were however substantial and Bibiyana immediately became the largest in the country. ${ }^{7}$ Initially many people were ambivalent about the site, experiencing both fear about a catastrophic 'blow out' of the gas (as had happened at another gas field, Magurchhara in 2005) ${ }^{8}$ and the hope of employment. Indeed, in the early days of construction, many hundreds of landless and land poor people were employed as labourers. More generally, people hoped that development (unnoti) would arrive, that the gas field would lead to connection to the global economy via employment and the growth of other industries around the site, rich opportunities for contractors and labourers alike.

Bibiyana's story should be situated within the broader picture of rapid industrialisation and economic growth in Bangladesh. Indeed, the country has recently become something of a development success story, reaching various targets of human development ${ }^{9}$ and being compared favourably to India on many indicators (Dreze and Sen, 2013: 58-64). As Feldman and Geisler describe, rampant property speculation and 'crony capitalism' are key features, as are dispossession and poverty (cf Feldman and Geisler, 2012; Adnan, 2013). Meanwhile the character of neo-liberal development, and in particular the role of multinationals in the extraction of natural resources, was causing serious political unrest. In 2006, shortly before our research at Bibiyana, protests against a proposed open cast mine in Phulbari, in north east Bangladesh, to be operated by Asia Energy led to the death of three and injury of around a hundred (Nuremowla, 2011; Faruque, 2012; Gain, 2006). Meanwhile national agitation centred around the content of Production Share Contracts with foreign companies, with activists arguing that these grossly exploit the country's natural resources, leading to large profits for the multinationals, generous backhanders for corrupt government officials and nothing for Bangladesh.

Whilst the presence of foreign multinationals is controversial few would dispute the need for energy security (cf Islam et al, 2008; Wesley, 2006). Over 2008-11 this was increasingly pressing; power shortages were hampering the industry which has

\footnotetext{
${ }^{6}$ The three gas fields which Chevron operates (in Bibiyana, Moulavi Bazzar and Jalalbad) contribute to around $50 \%$ of the country's natural gas. The gas is sold to Petrobangla, the national oil company. For more information see http://www.chevronbangladesh.com/business/\#b4 (accessed 06/07/15)

7 In 2014 the Bibiyana field further expanded and now has a capacity for producing 300 million cubic feet of gas a day.

${ }^{8}$ See http://www.ijstr.org/final-print/sep2014/A-Review-Over-Major-Gas-Blowouts-In-BangladeshTheir-Effects-And-The-Measures-To-Prevent-Them-In-Future.pdf (accessed 6/07/15)

${ }_{9}^{9}$ See http://hdr.undp.org/en/countries/profiles/BGD (accessed 19/02/14)
} 
motored Bangladesh's growth rate of $6.6 \%$ (in the first part of 2010). As a report by the Asian Development Bank stated in $2010^{\prime}$ '.... acute power and energy shortages have reduced Bangladesh's short term growth prospects.'10. Whilst Bangladesh's industrial and manufacturing sectors are almost completely dependent upon natural gas to produce electricity, agricultural production is largely dependent upon urea, a fertiliser produced from natural gas. Such was the need for energy that in the years leading up to our research power shortages caused riots at electricity stations ${ }^{11}$. Despite the development of sites such as the Bibiyana and frantic bids to develop off-shore reserves in the Bay of Bengal, the country is far from achieving energy security (Devare, 2008). Within this context Bibiyana is a crucial part of the country's development effort. Indeed, when it temporarily ceased production in June 2013 due to technological problems, the shortages were experienced across the country ${ }^{12}$.

Meanwhile during the development of the Bibiyana gas field the potentiality of the gas, an invisible form of wealth linked by pipelines to metropolitan centres, which could bring modernity and riches to those living above, seemed rich in possibilities (cf Weszkalnys, 20014). Indeed, the gas offered the possibility of modern and clean energy: no more cooking on earth stoves using firewood gathered by hand! As people told us, since Chevron were taking a local resource, they should pay them back by supplying employment and, at the very least, connection to the gas supply. By the mid 2000s many of the more prosperous Londoni houses had modern kitchens, with fridges and gas stoves that were either powered by canisters, or left unused and unconnected to the gas, for whilst the potential connection was vividly imagined and desired, in reality it was absent. In the house where I was staying for example, the cooker installed for the use of Londoni cousins on their visits to the desh was covered with dust, and never connected to the gas that lay under the fields. They used the kitchen for storing betel nut and rice, my friends laughingly told me. A similar scenario could be found up the road on the way to the South Pad. Here, a wealthy businessman had built a gleaming new gas station, ready for the heavy traffic that he believed would soon be passing. During our fieldwork, however, the pumps were unused and the building unfinished. What had been anticipated had never arrived.

Back in 2005 the anticipation of work, wealth and piped gas co-existed with substantial resistance to the gas field, fuelled by rumours that the gas was to be piped to India (Wesley, 2006: 77). 'Demand Resistance Committees' were set up and a series of demands put to Unocal: the rate of land compensation was high on the list, as was connection to the gas, the provision of a school, a hospital, a fertiliser factory and

\footnotetext{
${ }^{10} \mathrm{http}: / /$ www.adb.org/Documents/News/BRM/brm-201002.asp

${ }^{11} 11 \mathrm{http}$ ://www.asianews.it/news-en/Six-dead,-100-reportedly-wounded-in-Bangladesh-electricityprotest-5196.html (accessed October 14 2010)

${ }^{11}$ http://www.accessmylibrary.com/coms2/summary_0286-18709714_ITM

${ }^{11} \mathrm{http}: / /$ www.asianews.it/news-en/Six-dead,-100-reportedly-wounded-in-Bangladesh-electricityprotest-5196.html (accessed 15/10/10)

${ }^{12}$ See http://news.priyo.com/2013/06/23/production-bibiyana-resumes-79430.html (accessed $18 / 02 / 14)$
} 
improved roads. Today, people say that Unocal agreed to these stipulations, even though rates of compensation, the piping of gas and development of power plants were determined by the government. The negotiations took place in a context of keenly felt agitation: in the perspectives of landowners, they were about to lose a resource which sustained not only their households but those of many people around them and which was irreplaceable; for some it seemed almost like a loss of self. As one of the biggest land losers told us: 'The day they grabbed my land, I lost my words. If I remember that day I have to stop myself from going mad.'

In 2005 the road was blocked by protesters. The police were called, threats made by the District Commissioner, arrests made and writs issued. Yet whilst some leaders tried to hold out against the inevitable, others started to negotiate. By this time the compensation process was underway: this was for land and property taken in the building of the plant and the roads that surrounded it and paid to the owners, many of whom lived in the U.K. But although legally only landowners were due financial compensation many others were affected, for by the time construction was finished the local eco system was significantly altered. The high banked roads that linked the 'pads' blocked the flow of water over the fields during the wet season, leading to the water logging of some plots and aridity of others. Farmers noticed increased amounts of sand in the soil and complained bitterly about the culverts that Chevron had built : they were too small and had become blocked with waterweeds. The roads were also too high for the movement of cattle. Other people, mostly from the landless households, bemoaned the shrinking of the commons: less land meant fewer opportunities for gathering firewood, left over rice grains and fish and shrimp from fields that were no longer inundated in the wet season. Add to this the reduction of land available for sharecropping and receding opportunities for agricultural labour, and the squeeze on their livelihoods was increasingly painful. In their view, they were due compensation as much as the landowners.

Once the gas field was completed it was the largest such installation in Bangladesh, supplying over half the country's natural gas. It also became the site of a programme of 'community engagement', designed partly to quell local discontent and run by the Bangladeshi official in charge of Public Relations, plus a small team of 'community liaison officers' based in the gas field. The idea was that whilst the company could not give compensation to landless people whose livelihoods had been affected, they could offer a programme of community development, including that of 'Alternative Livelihoods.' Local discontent was particularly acute at the time, for the hopes of employment and inclusion that had existed during the initial stages of construction had, by 2007, been dashed. Whilst around five hundred labourers had originally been employed, once the site was completed most were laid off. These men were amongst the most disillusioned of the people we spoke to over 2008-11. They had been given regular jobs and incomes, they said, until they were suddenly 'sacked'. With the exception of wealthier and politically well placed individuals who had gained contracts to supply 
building materials or labour, disappointment and anger were common during the period of our research.

\section{A Moral Economy of Disconnection: Corporate Community Engagement in Bibiyana}

Whilst within the moral economy of connection local people expected much from Unocal-Chevron, those in charge of the corporation's programme of Community Engagement were acting within a quite different moral economy, based around disconnection. As their CEO told me in 2008, if conditions changed, perhaps because local politics became too tricky or the gas reserves were less than anticipated, the company would quickly pull out. Moreover the company did not wish to take the place of the government or development agencies. Their motivation, he candidly explained, was wholly profit driven. Community Engagement / CSR was 'good business'13. Thus whilst the company stressed the values of 'partnership' with local communities, they remained decidedly aloof from actual engagement or connections with the villages surrounding the gas plant, working entirely through a handful of members of the elite to set up their programmes which were run by NGOs. Vitally, the few local people who during our research worked as guards or labourers at the gas field were employed via contractors whilst the majority of the workforce were drawn from outside the area, and the community engagement personnel had little to do with the local people who told us that they never visited the villages, were unavailable and had never established an accessible office o(Gardner, Rana, Bashir and Ahmed, 2012).

Crucially, the programmes that the company offered were motivated by the ethics of 'sustainability', 'self help' and 'empowerment', key components of the moral economy of disconnection. These ethics effectively deny the long term social and economic connections that local people feel are their due, for they are aimed at an end point in which support is withdrawn rather than the ongoing relationships of the moral economy of connection. To this extent, they can be seen as a form of disconnect development (Gardner, 2012). Julia Elyachar makes a similar point in her witty description of 'anti-development development' , which, she argues, is what World Bank officials espouse in their enthusiastic embrace of 'empowerment' and micro-enterprise, taking place in the informal economy. Here, 'anti development development' is a winwin (at least for the World Bank) for it endorses the neo liberal rolling back of the state and structural adjustment whilst at the same time appealing to those protesting against globalisation and wishing to promote communities and the needs of 'the people'; large scale development projects and lending are seen as 'anti-community' and 'anti-people' (Elyachar, 2002: 496).

13 Interview notes, 2009 
By 2008, when we started our research, these programmes of disconnection had been launched after an earlier period of gifting in which Unocal appeared momentarily to be acting more like a local patron, playing its role in the moral economy of connection as sweets and tee shirts emblazoned with the company logo were distributed at random. Our informants described promises being made during this early period of the good things the corporation would bring: industrialisation, employment, new business opportunities as well as investment into schools and medical facilities. For example, many of our informants described how during 'community consultations' officials had implied that the roads linking the 'pads' would contribute to economic development and attract industry. Looking back on those days, a senior official told me that Unocal had made many mistakes and created 'unrealistic expectations' which Chevron later had to put right. Later I realised that this man had held the same post at Unocal so was responsible for all the mistakes that he was now criticising ${ }^{14}$.

After the gas field was inaugurated in 2007 the distribution of CSR gifts continued, though was now aimed at poverty alleviation and social welfare and included items such as slab latrines and building materials which were offered to poorer households whose homes had been damaged in floods ${ }^{15}$. In 2008 Chevron's Director of External Affairs explained to me that the earlier policy of ensuring financial compensation and 'free' gifts had not satisfied the local population, for the money was quickly spent and the gifts contributed nothing to the long term development of the area. Instead, what was required was a programme which would support the whole community and not lead to dependency. Following the global development ethics of anti-politics and disconnection, the new programmes started with Participatory Rural Appraisal exercises in which problems were diagnosed and the field of action delineated (Li, 2007: 246). The knowledge gained was written up in more reports, and the 'problem' (the loss of livelihoods to the gas field/ poverty) transformed into 'project goals'. Like all neo liberal development projects the solutions were technical: community groups were to be formed, training in literacy and other 'productive' activities offered alongside technical, supervisory and marketing support, all deeply reminiscent of the services offered by the countless NGOs working in Bangladesh (cf. Lewis, 2006; White, 1999; Stiles, 2002; Gauri and Galef, 2005; Karim, 2008).

Key to 'capacity building' was the setting up of Village Development Organisations (VDOs) which would involve committees of 'local leaders', who would choose beneficiaries for the credit and training. Through this mechanism a direct relationship between the donor and the recipients was avoided: local leaders and not Chevron would

\footnotetext{
${ }^{14}$ This strategy of the 'confession' of previous sins has been noted by other anthropologists of mining company CSR (Burton, 2002).
}

15 According to literature produced by Chevron, they distributed 1,300 sanitary latrines among poorer households living near the field in the first year of operations, plus another 1,400 by March 2007 (Bibiana Gas Field : 1st Anniversary Report) 
be dealing with the actual recipients of the gifts. As a further extension of the corporate ethic of detachment, an 'Alternative Livelihoods Programme' would be implemented by the NGO Friends in Village Development Bangladesh who would work with the VDOs to draw up lists of needy recipients. Thus whilst the initial distributions of Unocal goodies echoed the largess of Londoni returnees, the VDOs directly replicated patronage relations. Quickly monopolised by the local elite the result was that those that had connections with particular patrons accessed the development gifts whilst others were excluded, a clear case of rural elites acting as gate keepers to development benefits (see Pattenden, 2011; Shah, 2010). VDOs should be elected in secret and include minority Hindu and landless representatives, we were told by disgruntled people left off the lists, a recommendation we passed onto Chevron, who later responded to these and other criticisms of their programmes by commenting that 'elite capture' was only to be expected ${ }^{16}$.

Here we reach the deeply contradictory nature of Chevron's gifts, for whilst the programme seemed to replicate existing relations of patronage, echoing the existing moral economy of support and obligation to the poor, instead of following through with established social relationships and charity, what they now offered were programmes aimed at 'empowerment' and sustainability, which denied the reciprocity and long term commitments to the poor that were core to the local moral economy of connection. Indeed, rather than the long established local and transnational ethic of 'shahajo' (help), lying at the core of the Alternative Livelihoods Programme was its antonym: not help, but self-help. The term was repeated, mantra like, by officials in Chevron and the slogan 'Helping People to Help Themselves' displayed on a banner inside the NGO offices. As the Chevron's British CEO told me in Dhaka, the locals of Bibiyana 'are a proud people', who eschew hand-outs and want to be helped-to-help-themselves. As he put it: You know ... "give a man a fishing rod" ...17

Yet as we have seen, the local economy of connection runs counter to this romantic vision of self reliant peasants made happy with fishing rods. Rather, what people had anticipated were jobs and inclusion in economic growth as well as long term support from the corporation. Failing that, they should be given compensation, like those whose land had been forcibly acquired. After all, as one man put it This company have been taking from our land, yet they pay us nothing! Small wonder that the programme of Alternative Livelihoods was widely criticised by local people. Perhaps they recognised that, as Andrea Cornwall has pointed out, within contemporary development discourse 'doing it for yourself' has become 'doing it by yourself.' (Cornwall, 2010: 3). Indeed, as Jonathan Pattenden describes in South India, rather than addressing the true causes of poverty - class relations and in India's case the withdrawal of the state from development - Self Help Groups: ' provide low cost, highly visible anti-poverty

16 This comment was made to an organisation publishing a summary of the research who approached Chevron for a response, and transmitted to me via email in 2012.

17 Interview notes, 03/12/08 
initiatives .... that help forestall social instability in the context of "jobless growth" and stagnation in the rural sector.' (Pattenden, 2010: 509).

Micro credit, offered to women and their micro-enterprises, is an important element of disconnected development, and is standard NGO fare, despite the increasing critiques of its outcomes (cf Karim, 2008) ${ }^{18}$. Predictably, in Bibiyana this was the cornerstone of the Alternative Livelhoods Programme. Administered by the VDOs, loans and savings programmes were made available to small scale entrepreneurs to fund a variety of livelihood activities, all of which required training and were directed to external markets. Goat rearing, fisheries and sewing projects for women, were examples. The latter failed to take off; not only did the young women trained to embroider quilts complain of how long it took for such a small reward, but by the end of the project many had married and moved away. Yet despite their shaky uptake, the initiatives had the avowed aim of producing self reliant entrepreneurs; With its stress on credit, training, and improving access to markets for those with the greatest capacity, the programme replicated the unspoken norms of neo-liberal capitalism, described by Ong as populated by : 'free individuals who are then induced to self-manage according to market principles of discipline, efficiency and competitiveness.' (2006: 4).

The principle of self reliance extended to the idea that 'the community' should contribute to the upkeep of the development gifts. Take the smoke free chulas (stoves), which I had seen discarded in Halema's yard ${ }^{19}$. An NGO field officer explained to me that to encourage people to care properly for the stoves, they were 'sold' to recipients at a cost of two hundred taka ${ }^{20}$. In terms of disconnected development such initiatives encourage responsibility and sustainability. As we have seen, however, recipients did not always behave as required: Halema's stove lay unused and discarded whilst other people expressed anger that they had been asked to pay for the gift, an oxymoron if ever there was one. Other gifts came with similar conditions. Two 'Smiling Sun' medical clinics were built, run by another NGO and partly funded by the donations of Londonis. These provided diagnostic services but not medicine, with a programme of outreach health workers, and an ambulance which could take patients to the nearest hospital in Sylhet, though at a cost. Our research in 2008-11 showed that the poorest households did not use these services since in their view there was little point in getting a diagnosis if they could not afford the prescribed medicines. Meanwhile whilst not actually building a school, the company provided support for four high schools in the area, via the funding of teachers and teaching materials, the distribution of school uniforms and providing several hundred scholarships for pupils each year ${ }^{21}$.

\footnotetext{
18 For studies of micro credit in Bangladesh see : Kabeer, 2001; Datta, 2004; Rudman and Morduch, 2013; Pitt et al, 2006

${ }^{19}$ For discussion of the role of such stoves in development, see Crewe, 1997

${ }^{20}$ At the time of the research a male day labourer might expect around 180 taka for a day's work.

21 Bibyana Gas Field First Anniversary Report, 2008: 39
} 
Overall, the aim of the programmes, I was told, was 'empowerment'. As an official declared at a workshop on CSR in Dhaka, in which he had showed a glossy power point presentation of the corporation's development gifts: "All we want to do is empower people." What did he mean? He surely could not be alluding to the radical sense of the term, with its Frierian roots and objectives of political consciousness raising (Friere, 1970). How, indeed, could he imagine that his company, which had been complicit in the forcible loss of land, had no grievance procedures and refused to share its social, health and environment impact assessments, might enable local 'empowerment'? The answer is that by using such terms the programme and its directors were attempting to elide themselves with morally virtuous disconnected development, avoiding the ethical contamination of patronage and reciprocity, but failing to recognise the complex and morally muddy terrain in which they were operating. Like 'sustainability' they had created an oil company oxymoron (Kirsch, 2010; see also Sawyer, 2010). As Cornwall has pointed out, in 'Development Speak' terms such as empowerment allow a fuzzy, feel-good factor; these are 'words that admit no negatives, words that evoke Good Things that no-one could possibly disagree with.' (Cornwall, 2010: 2; see also Sharma, 2008). More generally in the world of Development concepts which may have originally have carried one set of (often radical) meanings are apt to lose their way, becoming flattened or meaning an array of different things to different people (Cornwall and Eades, 2010; Batliwala,2007).

How were these oxymoronic gifts to be reciprocated? Whilst aimed at creating moral virtue by avoiding patronage and on-going social relationships recipients were expected to 'pay back' via particular types of behaviour (self reliance) and collective performances which would add to the publically visible ethical virtue of the corporation. Whilst the rituals of gratitude took place in Bibiyana, including 'handing over ceremonies' in which the gift - of money, sewing machines, or even housing - was make public (Rajak, 2008) the pay-back for Chevron depended upon their transformation into merit in the global arena via reports and other literature which narrated success for an international audience. For example, the Bibiyana Newsletter produced by Chevron in 2008 includes nine photographs of handing over ceremonies, in twenty four pages. Amongst other good things, the report gushingly describes how for women whose houses had been damaged in floods: 'Chevron gave them the chance to restart their lives afresh by rebuilding their homesteads' whilst local farmers are excited at being trained in scientific methods (Chevron, 2008). Here, the presentation of romantic South Asian villages and culture, with which, it is implied, Chevron is a caring partner rather than a hierarchically powerful patron, comes into its own, Pieces of embroidery, sewn by the women of the project and offered to visiting dignitaries and bemused anthropologists are described as follows:

This exquisite embroidered quilt is the product of a Bengali tradition that goes back a long way ... it is made by rural women during their leisure, particularly during the rainy season or before the bitter winter invades the villages of this deltaic region .... Under the livelihood project of Chevron Bangladesh, women from 
the villages of the Bibiyana gas field area have taken up quilt stitching as means to generate income and employment ${ }^{22}$

\section{'What's the Point?' : Critiquing the Gift of Self Help}

Whilst some recipients were happy to perform gratitude for the corporation, others were less keen. For example, Khaled, who had been featured in the opening pages of Chevron's globally circulated CSR Report (2007) as 'a villager who owns a family owned fishing business' told me that he was embarrassed that his photograph had been taken when he was knee deep in mud and wearing working clothes. He had gained credit from the programme and was at the time working as a contractor for the company, but remained ambiguous about the gas field. Meanwhile the offerings of 'empowerment' and 'self help' were not always well received by those for whom the costs contradicted their expectations of compensation and connection. The company was using their gas, people said, but they were not even connected to the gas supply. Instead, they had been given smoke free chulas! This palpable disappointment was reflected in many of our interviews. They had anticipated work, infra structure and modern services but it had not arrived. There was no school, just a programme of stipends, and no hospital, just a community clinic, the costs of which they had to partly cover. As one man put it:

Chevron has established a community hospital but we don't benefit from it. What's the point if all the expenses are born by us? First you have to pay 40 taka to register, then you have to pay 20 taka for every visit. None of the medicine is free. Once I used the ambulance, but to get to Sylhet it cost 1000 taka.

In the following analysis Chevron are placed at the centre of the 'big disease' of poverty and disenfranchisement, responsible for its cure. They are not 'partners', but are placed almost in the role of the state, their responsibility for the well being of their 'communities' part of their role in the area.

Say you have a big disease and Chevron is giving us a Paracetemol. If the disease is big the treatment should be big too. You need a big doctor, diagnosis, operations, expensive medicine, good care and so on. But Chevron want to satisfy us by providing Paracetemol?

The situation is eerily similar to that described by Welker in her account of the 'unruly subjects' of participatory development in the Batu Hijau mine operated by Newmont in Indonesia (Welker, 2012). Identified as a security risk by the company, local farmers were given training in agricultural methods in an attempt to get them to behave as productive farmers. Yet whilst the training attempted to instil neo-liberal subjectivities the farmers were unwilling and resistant to many of its participatory methods. This was not simply because the workshop style methods did not translate; it was also because,

${ }^{22}$ Taken from a card included with the packaging of the quilt. 
as the farmers insisted, they did not want training in agriculture. Instead, they were dependent upon the mine which 'owed them more than just a sense of enterprise, empowerment and autonomy.' (ibid: 402)

\section{Conclusion}

Whilst to date the anthropology of the corporate gift has largely analysed the exchange in terms of the extension of capitalist power, important questions remain concerning the manner in which the gifts are received, or as Jamie Cross puts it, the ways in which the transaction allows donors and recipients to 'make themselves and know themselves afresh' (Cross, 2014: 140). In this paper I have argued that one way in which we might frame the differing expectations, roles and relationships that the gifts involve, and the 'knowing' that is revealed is via the concept of moral economy. In Bibiyana, the CSR gifts offered by Chevron over 2008-11 indicate that the corporation were working within a moral economy of disconnection quite at odds with the local moral economy of connection.

Based on the local economy of land use, long term relationships of patronage and 'helping' across transnational space, within the economy of connection local people expected that Chevron should act as a patron, providing services and development goods that were owed them in return for their use of local resources. In the longer term the arrival of the corporation prompted the anticipation of modernisation and economic growth, and all the good things that these might bring. In contrast however, Chevron was motivated not only by the 'corporate ethic of detachment' (Cross, 2011), but also the values of neo liberal 'anti development development' (Elyachar, 2002). With their tropes of self help and empowerment the programmes of 'Community Engagement' chimed with the First World consumers, employees and opinion formers for whom questions of ethics and certain forms of morality are placed at the centre of 'good' business practice (Rajak, 2011). Through such programmes the dubious nature of natural resource extraction is expiated, yet rather than being offered to people with whom there is a social contract it is offered to romanticised villagers and communities who are 'empowered' and freed from patronage, which, it is assumed, they wish to escape from. Like other oxymorons, the gift of empowerment and self reliance carries considerable rhetorical power but aims to ultimately absolve the company from long term commitment or connections.

It is within this context of overlapping economies of connection and disconnection and the shifting expectations, anticipation and disappointment evoked by Chevron's presence that the paradox with which I started this paper makes sense. When people in the villages surrounding the gas field announced that Chevron 'give nothing', what they meant was that Chevron had neither compensated them for their use of local gas via the provision of jobs and economic development and nor were they behaving like patrons, insisting that what appeared to be gifts should be 'paid for' to instil the appropriate 
values amongst recipients. By offering disconnected development, Chevron were thus 'giving nothing', for in Bibiyana, connection to people and or material benefits in compensation for local resource use was required. Meanwhile, rather than being given to the plucky and independent peasants of the corporate imagination, the gift of CSR was offered to a population whose deep rooted dependency on those overseas and passionately felt desire for inclusion and modernity, not to say connection to the gas and all its potential, led to protests and complaints which CSR executives, stung by the lack of gratitude, dismissed as the local people being 'very demanding.'

\section{References Cited}

Adams, C. 1987 Across Seven Seas and Thirteen Rivers: Life Stories of Sylheti Pioneers in Britain. London: Tower Hamlets Arts Project.

Adduci, M. 2009 'Neoliberal Wave Rocks Chilika Lake, India: Conflict over Intensive Aquaculture from a Class Perspective.' Journal Of Agrarian Change [serial online]. 9(4):484-511.

Akram-Lodhi, A. H. 2009 'Modernising subordination? A South Asian perspective on the World Development Report 2008: Agriculture for Development.' The Journal of Peasant Studies, 36:3; pp 611-619

Amrith, S. 2013 Crossing the Bay of Bengal: The Furies of Nature and the Fortunes of Migrants Harvard University Press

Batliwala, S. 2007 'Taking the power out of 'empowerment': an experiential account.' Development in Practice Vol 17, Issue 4-5 pp 557-565

Burton, T. 2002 'When corporations want to cuddle', in G. Evans, J. Goodman and N. Lansbury (eds) Moving Mountains: Communities Confront Mining and Globalisation. London: Zed Press, pp. 109-25.

Centre for Women and Child Studies, 2006 'Baseline Study of Unocal Working Area' Dhaka

Chevron Publications 2008 Bibiyana Gas Field First Anniversary Report. Dhaka: Chevron

Cons, J., \& Paprocki, K. (2010). Contested Credit Landscapes: microcredit, self-help and self-determination in rural Bangladesh. Third World Quarterly,31(4), 637-654.

Corbridge, S., and Shah, A. 2013. "Introduction: the underbelly of the Indian boom." Economy and Society 42.3: 335-347. 
Cornwall, C. 2010 'Introductory Overview- buzzwords and fuzzword, deconstructing development discourse' in Cornwall and Eade, D eds. 2010 Deconstructing Development Discourse: Buzzwords and Fuzzwords Practical Action Publishing : London pp 1-19

Crewe, E. 1997 "The silent traditions of developing cooks." Discourses of development: anthropological perspectives pp 59-80.

Cross, J. 2011 "Detachment as a corporate ethic: Materializing CSR in the diamond supply chain." Focaal 2011.60 (2011): 34-46.

Cross, J. 2014 Dream Zones: Anticipating Capitalism and Development in India Pluto Press: London

Datta, D. 2004 "Microcredit in rural Bangladesh: Is it reaching the poorest?." Journal of Microfinance/ESR Review 6.1; pp 55-82.

Devare, S. ed. 2008 A New Energy Frontier: The Bay of Bengal Region Institute of South Asia Studies

Dolan, C and Rajak, D. eds forthcoming The Anthropology of Corporate Social Responsibility. Routledge: London

Dreze, J and Sen, A. 2013 An Uncertain Glory: India and its Contradictions Penguin : London

Edelman, M. 2005 'Bringing the Moral Economy back in... to the Study of 21st-Century Transnational Peasant Movements. American Anthropologist,107(3), 331-345.

Elyachar, J. 2002. 'Empowerment money: the World Bank, non-governmental organizations, and the value of culture in Egypt.' Public Culture, 14(3), 493-513.

Faruque, 0. 2012 The Phulbari Movement: Political Struggle against Neoliberal Development in Bangladesh. University of Waterloo-Wilfrid Laurier University 2012.

Feldman, S. \& Geisler, C. 2012 'Land expropriation and displacement in Bangladesh', The Journal of Peasant Studies, 39:3-4, pp 971-993

Ferguson, J. 2005 'Seeing it like an oil company: space, security and global capital in neo-liberal Africa', American Anthropologist 107(3): pp 377-82.

Friere, P. 1970. "Pedagogy of the oppressed." New York: Herder and Herder.

Frynas, G. 2005 "The false developmental promise of corporate social responsibility: Evidence from multinational oil companies." International affairs81.3 (2005): 581-598. 
Gain, P. 2006 "Killings in Phulbari Ignite Unstoppable Protest: Local Communities Stand Strong against Open Cut Mining." Society for Environment and Human Development, (no date)

Gardner, K. 1995 Global Migrants, Local Lives: Migration and Transformation in Rural Bangladesh. Oxford: Oxford University Press.

Gardner, K. 2008 'Keeping connected: security, place and social capital in a Londoni village in Sylhet', Journal of the Royal Anthropological Institute NS 14: 447-95.

Gardner, K 2012 Discordant Developments: Global Capital and the Struggle for Connection in Bangladesh Pluto Press, London

Gardner, K. and Ahmed, Z. 2009 'Degrees of separation: informal social protection and relatedness and migration in Biswanath, Bangladesh', Journal of Development Studies 45(1): 124-49.

Gauri, V, and Galef, J. 2005 "NGOs in Bangladesh: Activities, resources, and governance." World Development 33.12 : 2045-2065.

Gurhathakurta, M. and van Schendel, W. eds 2013 The Bangladesh Reader: History, Culture, Politics Duke University Press : Durham

Hossain, D. 2013 Boundaries Undermined: The Ruins of Progress on the Bangladesh Border Hurst and Co : London

Inden, R. 1990 Imagining India Indiana University Press

Islam, A. 2002. "The informal institutional framework in rural Bangladesh." in Hands not land: how livelihoods are changing rural Bangladesh : pp 97-104. Available at http://theidlgroup.com/documents/handsnotlandbook.pdf\#page=99 (accessed 21/02/14)

Islam, R. M., M., Islam, R. and Alam Beg, R. 2008 "Renewable energy resources and technologies practice in Bangladesh." Renewable and Sustainable Energy Reviews 12.2 : pp 299-343.

Ito, S. 2002 'From Rice to Prawns: Economic Transformation and Agrarian Structure in Rural Bangladesh' The Journal of Peasant Studies, 29:2, pp 47-70

Jansen, E. 1987 Rural Bangladesh: Competition Over Scarce Resources Dhaka : Dhaka University Press

Karim, L. 2011 Microfinance and its discontents: Women in debt in Bangladesh. U of Minnesota Press.

Kabeer, N. 2001 "Conflicts over credit: re-evaluating the empowerment potential of loans to women in rural Bangladesh." World Development 29.1 (2001):pp 63-84. 
Kabeer, N. 2002 'Citizenship, affiliation and exclusion: perspectives from the South', IDS Bulletin 33(2)pp 1-15.

Kapelus, P. 2005 'Mining, CSR and "the community": the case of Rio Tinto, Richards Bay Minerals and the Mbonambi.' In The Journal of Business Ethics (39) pp 275-296

Karim, L. 2008 "Demystifying Micro-Credit The Grameen Bank, NGOs, and Neoliberalism in Bangladesh." Cultural Dynamics 20.1 pp 5-29.

Kirsch, S. 2010 'Sustainable mining', Dialectical Anthropology 34(3) pp 87-93.

Korf, B., Habullah,S., Hollenbach, P., and Klem, B. 2010 "The gift of disaster: the commodification of good intentions in post-tsunami Sri Lanka." Disasters 34, pp 560577.

Lewis, D. 2004 "On the difficulty of studying 'civil society': reflections on NGOs, state and democracy in Bangladesh." Contributions to Indian sociology 38.3 : 299-322.

Lewis, D. 2011 Bangladesh: Politics, Economy and Civil Society Cambridge University Press: Cambridge

Li, Tania Murray 2007 The Will to Improve: Governmentality, Development and the Practice of Politics. Durham, NC: Duke University Press.

Nuremowla, S. 2012 Resistance, Rootedness and Mining Protest University of Sussex Phd thesis

Ong,A. 2006 Neoliberalism as Exception: Mutations in Citizenship and Sovereignty. Durham, NC: Duke University Press.

Mosse, D. 2005 Cultivating Development: An Ethnography of Aid Policy and Practice. London: Pluto Press.

Parry, J. 1986 'The gift, the Indian gift and “the Indian gift”', Man 21(3): 453-73.

Pattenden, J. 2010 'A neo-liberalism of civil society? Self-help groups and the labouring class poor in rural South India', Journal of Peasant Studies 37(3): 485-512.

Pattenden, J. 2011 'Gatekeeping as accumulation and domination: Decentralization and class relations in rural south India'. Journal of Agrarian Change, 11(2), 164-194.

Pitt, M., Khandker, S. and Cartwright, J. 2006 "Empowering women with micro finance: evidence from Bangladesh." Economic Development and Cultural Change 54.4 pp: 791831.

Prno, Jason, and D. Scott Slocombe 2012 "Exploring the origins of 'social license to operate'in the mining sector: Perspectives from governance and sustainability theories." 
Resources Policy 37.3: pp 346-357. Rajak, D. (2008). I Am the Conscience of the Company. Economics and morality: anthropological approaches, 211.

Rajak, D. 2011 In Good Company: An Anatomy of Corporate Social Responsibility. Stanford, CA: Stanford University Press.

Rogers, D. 2012 'The materiality of the corporation: Oil, gas, and corporate social technologies in the remaking of a Russian region'. American Ethnologist, 39: pp 284-296

Roodman, D, and Morduch, J. 2013 "The impact of microcredit on the poor in Bangladesh: Revisiting the evidence." Journal of Development Studies ahead-of-print (2013): 1-22.

Samaddar, R. 1999 The Marginal Nation: Transborder Migration from Bangladesh to West Bengal. Dhaka: Dhaka University Press.

Sawyer, S. 2010 "Human energy." Dialectical anthropology 34.1 pp: 67-75.

Scott, J. C. 1977 The moral economy of the peasant: Rebellion and subsistence in Southeast Asia. Yale University Press.

Scott, J. 1999 Seeing Like a State : How Certain Schemes to Improve the Human Condition have Failed Yale Agrarian Studies : Yale University

Shah, A. 2010 In the shadows of the state: Indigenous politics, environmentalism, and insurgency in Jharkhand, India. Duke University Press.

Shapan A. 2013 'Land grabs and primitive accumulation in deltaic Bangladesh: interactions between neoliberal globalization, state interventions, power relations and peasant resistance' The Journal of Peasant Studies, 40:1; pp 87-128

Sharma, A. 2008. Logics of empowerment: Development, gender, and governance in neoliberal India. U of Minnesota Press. Chicago

Shever, E. 2010 'Engendering the Company: Corporate Personhood and the "Face" of an Oil Company in Metropolitan Buenos Aires' PoLAR: Vol. 33, No. 1. pp 26-45

Shever, E. 2012 Resources for Reform: Oil and Neoliberalism in Argentina. Stanford University Press.

Stiles, K. 2002 "International support for NGOs in Bangladesh: Some unintended consequences." World Development 30.5 (2002): 835-846.

Stirrat, J. And Henkel, H. 1997 'The development gift: the problem of reciprocity in the NGO world.' In Annals of the American Academy of Political and Social Science Vol 554 November pp 66-80 
Thompson, E. P. 1971 'The moral economy of the English crowd in the Eighteenth Century' . Past \& present, 50(1), 76-136.

Toufique, K. and Turton, C. 2002 Hands not Land: How Livelihoods are Changing in Rural Bangladesh. Bangladesh Institute of Development Studies.

van Schendel, W. 1981 Peasant Mobility: The Odds of Life in Rural Bangladesh Assen: Van Gorcum

Walker, K. L. M. 2008 'Neoliberalism on the Ground in Rural India: Predatory Growth, Agrarian Crisis, Internal Colonization, and the Intensification of Class Struggle', The Journal of Peasant Studies, 35:4 pp 557-620

Welker, M. 2009 '"Corporate security begins in the community" : mining, the CSR industry and environmental advocacy in Indonesia.' In Cultural Anthropology 24(1) pp 142-179

Welker, M. 2012, The Green Revolution's ghost: Unruly subjects of participatory development in rural Indonesia. American Ethnologist, 39: pp 389-406.

Welker, 2014 Enacting the Corporation: An American Mining Firm in Post Authoritarian Indonesia University of California Press; Berkely

Wesley, M. 2006 Energy Security in Asia Routledge, London

Weszkalnys, 2014 'Geology, potentiality, speculation: on the interdeterminancy of natural resources'

White, S. 1999 "NGOs, civil society, and the state in Bangladesh: The politics of representing the poor." Development and change 30.2: 307-326.

Wood, G. 2003 "Staying secure, staying poor: the "Faustian Bargain"." World Development 31.3: 455-471.

Yeh, E. T. 2013 Taming Tibet: Landscape Transformation and the Gift of Chinese Development Cornell University Press: Ithaca

Zalik, A. 2004 'The Niger Delta: 'Petro Violence' and 'Partnership Development.' In Review of African Political Economy Vol 31, No 101 pp 401-424 